\title{
Assessment of groundwater resources potential using geoelectrical method and slug test in Tegal District, Central Java Province, Indonesia
}

\author{
Wahyu Wilopo ${ }^{1,2 *}$, Moch Hasmannoor Rachman ${ }^{1,2}$, and Doni Prakasa Eka Putra ${ }^{1,2}$ \\ ${ }^{1}$ Department of Geological Engineering, Universitas Gadjah Mada, Yogyakarta 55281, Indonesia \\ ${ }^{2}$ Center for Disaster Mitigation and Technological Innovation (GAMA-InaTEK), Universitas Gadjah Mada, Indonesia
}

\begin{abstract}
Water resources are essential to support everyone in the world, and one of its sources is groundwater. Many areas in Indonesia rely on groundwater to meet their daily needs due to the lack of surface water resources. However, not all-districts have detail information about groundwater resources such as in Tegal District, Central Java Province, Indonesia. Land use planning without the support of information on water resources will cause many problems. Therefore, this study aims to assess groundwater resources in Tegal District using the geoelectrical method and slug test. The research was conducted by geoelectrical survey in 8 locations, measuring groundwater level from the nearest point, and two slug tests. The result of the survey shows that five types of materials in the area are clay, silt, sand, breccia, and lava. The sand layer is an aquifer, and it consists of two layers. The sand layer has a permeability of $6.68 \mathrm{~m} \mathrm{~d}^{-1}$. However, the clay has a permeability of $1.46 \times 10^{-3} \mathrm{~m} \mathrm{~d}^{-1}$. The moderate potential of groundwater resources with transmissivity value of more than $50 \mathrm{~m}^{2} \mathrm{~d}^{-1}$ lies in the middle of the district.
\end{abstract}

\section{Introduction}

Groundwater is the most significant source of fresh water on the earth, with an amount of about $30.1 \%$ [1]. However, its utilization is still not optimal in some areas where surface water resources are available. In addition, detailed information is not readily available in some areas. This limitation often causes regional development problems since different types of land use require it. When the land-use site is in areas with limited surface water, this will cause hardship for the community and create barriers to economic development.

Groundwater has become the main source of water in areas with limited surface water resources. It has advantages in terms of quality and quantity [2]. In general, its presence is highly influenced by three major factors, including topography, hydrology, and geology [3]. Indonesia has a tropical climate with very high rainfall. In Indonesia, 263 groundwater basins with an estimated total of 522.2 billion $\mathrm{m}^{3} \mathrm{yr}^{-1}$ have been identified. Eighty are located in Java and Madura islands, with the resources of 43.314 billion $\mathrm{m}^{3} \mathrm{yr}^{-1}$ [4].

The research on the potential of groundwater has been performed directly and indirectly using different methods. One of the indirect methods is geophysical, in which the interpretation of the aquifer is based on the material properties of the earth [5]. This method has advantages over others because of its low cost and rapid processing [6]. Geoelectric is a geophysical method often used for the exploration of groundwater. It has been widely used to find porous aquifers [710], fractured aquifers [11], and to identify freshwater from saline water $[12,13]$.

A survey by geophysical method provides information on the potential of rock layers that have the potential to drain groundwater and its distribution both vertically and horizontally. Therefore, it is necessary to do a permeability test to understand the capability of the rock layers in draining. These tests can be conducted both in the laboratory and field. However, field testing gives accurate results due to the small potential for errors in preparing soil/rock samples [14]. Field analysis of permeability can be conducted by pumping [15] or constant head tests performed in the boreholes $[16,17]$.

Lack of information on groundwater resources in the Tegal District has become a severe issue for developing water resources management, especially for drinking purposes. In addition, it presents a problem during the dry season with decreasing surface water for agricultural irrigation. Therefore, this research aims to assess information on groundwater potential in the Tegal District by integrating geoelectrical surveys and slug tests.

\section{Methodology}

The research area is located in Tegal District, Central Java Province, Indonesia, as shown in Figure 1. It is around $876.1 \mathrm{~km}^{2}$ with 18 sub-district [18]. In the north, this research location is bordered by the Java Sea and in the east by Pemalang District. Banyumas and Brebes Districts border the south and west, respectively. 
A geoelectrical method was conducted by the Schlumberger to estimate the type and thickness of the material layers vertically. The vertical electrical sounding (VES) was used to identify the resistivity in the subsurface. Eight points of the geoelectrical survey were formed, as shown in Figure 2. Furthermore, the measurement of the groundwater level was conducted in the nearest dug well to support the geoelectrical interpretation. Its survey used resistivity meter Oyo McOhm Model 2115A Mark 2 with the length of line 500 meters for each measurement. Therefore, the precision of interpretation reaches 125 meters [19]. The line of the geoelectrical survey is straight and parallel with the strike of the material layer. It was performed by injecting electric current into the ground. This survey uses two electrodes to deliver the electric current and two other potentials for reading the voltage and resistivity after the current passed to the earth materials [20]. They are installed in the ground with a certain and regular distance between electrodes and potentials. The two electrodes have a linear relationship with their depth of penetration towards the layers of material. The apparent resistivity value is controlled by measured potential $(V)$, the electrical current $(I)$, and geometric factor $(K)$. It can be calculated using the equation as follow:

$$
\rho_{a}=\frac{K \Delta V}{I}
$$

where $\rho_{a}$ is the apparent resistivity (ohm-m), $I$ is the electrical current (Amp), $\Delta V$ is the potential difference (volts), and $K$ is known as the geometric factor, which depends on the position of the electrode and earth materials stratification in the subsurface. Analysis of resistivity data used Progress V3.0 software.

The hydraulic permeability of the aquifer is estimated using a slug test [21], which has more advantages compared to the pumping test. It is cheaper, much quicker, and does not necessarily need monitoring well [22]. The tests were conducted in the two points for representing different materials, as shown in Figure 2. The slug test was conducted by pumping with a constant rate of $10 \mathrm{~L} / \mathrm{s}$ until the groundwater becomes stable, and it will be stopped. The initial groundwater level and depth after pumping stopped are measured regularly until a normal state is reached. Estimation of permeability is achieved through the plotting of groundwater level recovery data in the semi-log graph. The equation for calculating permeability is given below:

$$
K=\frac{r^{2} \ln \left(\frac{L_{e}}{R}\right)}{2 L_{e} t_{37}}
$$

where $K$ is hydraulic conductivity ( $\mathrm{m} /$ day), $r$ is the radius of the well casing (m), $R$ is the radius of a well screen or sand pack (m), $L_{e}$ is the length (m), and $T_{37}$ is the time it takes for the water level to rise $37 \%$ of the initial change [23].

The potential of groundwater resources was estimated by transmissivity value [24]. The transmissivity value was calculated using the equation as follow:

$$
T=K x b
$$

where $T$ is transmissivity $\left(\mathrm{m}^{2} /\right.$ day), $K$ is permeability $(\mathrm{m} /$ day $)$, and $b$ is the thickness of the saturated aquifer (m).

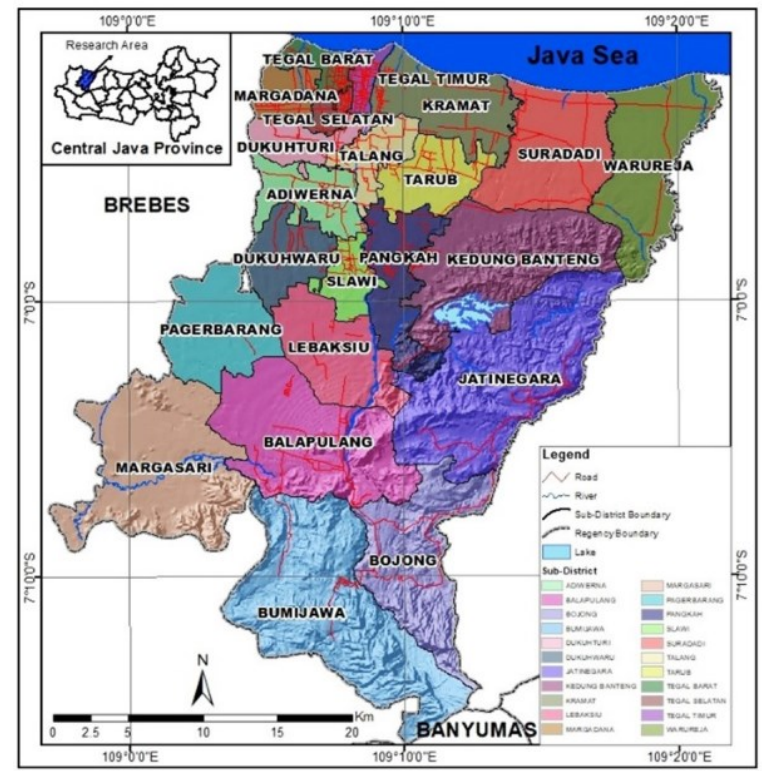

Fig. 1. Research area in Tegal District, Central Java Provice, Indonesia

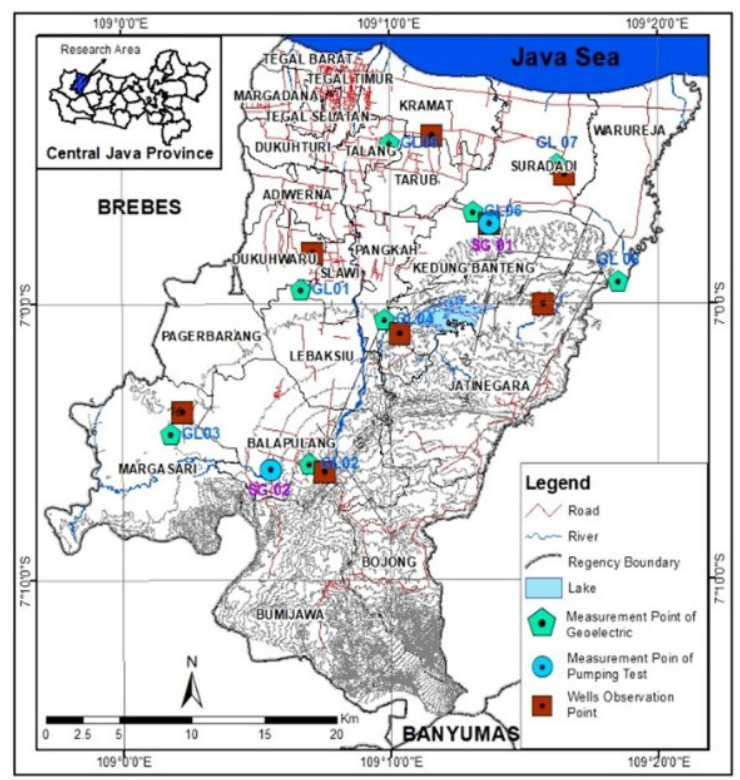

Fig. 2. Groundwater level measurement points, geoelectrical survey points, and slug tests location in Tegal District.

\section{Results and discussion}

The district of Tegal has a tropical climate with monthly temperatures between $27.18^{\circ} \mathrm{C}$ and $28.57^{\circ} \mathrm{C}$ [18]. The average annual rainfall from 2010 to 2018 is 1527.6 $\mathrm{mm} \mathrm{yr}^{-1}$. The evapotranspiration was calculated using the Turc equation [25] and was approximately 911.92 $\mathrm{mm} \mathrm{yr}^{-1}$. The runoff in this watershed was estimated to be $453.22 \mathrm{~mm} \mathrm{yr}^{-1}$ using the Sarma method [26]. Therefore, the groundwater recharge in Tegal District was estimated at around $162.46 \mathrm{~mm} \mathrm{yr}^{-1}$.

The lowlands of the Tegal district consist of alluvial and lahar deposits of the Slamet volcano, while 
the highlands are dominated by volcanic materials [27]. Almost all of the volcanic rocks were wholly weathered. Alluvial deposits consist of clay, silt, sand, and gravel, including products from the river and marine process. Volcanic materials from Mt. Slamet consist of breccia, lava, tuff, and intrusive rock.

\subsection{Aquifer configuration}

The result of geoelectrical measurements was combined with surface geological observation and regional data to interpret the type of lithology. The analysis of each geoelectrical survey has a root mean square (RMS) error of less than $10 \%$, and their resistivity values are shown in Table 1. Based on these values, and regarding previous studies [28, 29], the earth material layer can be divided into five types, clay, silt, sand, breccia, and lava. The clay layer is characterized by resistivity value from 1.9 to $9.99 \mathrm{ohm}-\mathrm{m}$. This layer is dominated in the northern area of the Tegal District, with thickness up to 110 meters. The material with resistivity value around 11.24 to $17.97 \mathrm{ohm}-\mathrm{m}$ is interpreted as the silt layer.

The unit of sand is located in the center of the research location, where the distribution is not continuous. It is interpreted from the resistivity value between 20.01 to 129.68 ohms-m. Furthermore, the sand has two layers, which were separated by clay. The breccia unit is interpreted from the resistivity value between 135.46 to 201.68 ohms-m, and more than that is interpreted as lava.

The sand unit is an excellent carrier of water because of its porosity and permeability. The clay layer has high porosity with low permeability. Therefore, it can be categorized under the aquiclude [23]. On the contrary, the silt layer is classified under aquitard since its transmission is in a small amount. Besides, breccia and lava can not transmit groundwater because of their low permeability. However, they become a good aquifer when fractured.

Based on the result of each geoelectrical interpretation of the lithology, a fence diagram was created, as shown in Figure 3. The sand layer as an aquifer is distributed continuously from the south to the north. Two layers of sand have been identified. The first layer of sand in the south reaches up to $13 \mathrm{~m}$ deep from the surface. It being gradually thinned to the north and transformed into a clay layer. There is a second layer of sand under the clay, which has the potential to become a confined aquifer.

\subsection{Permeability of rock}

Slug test was conducted to estimate earth materials permeability in the field. It was performed in the Balapulang and Suradadi Sub-district. Both of them were conducted in the shallow layer. The permeability value was calculated using equation two of the slug test data. Based on the result of the slug test in the Balapulang Sub-district, the upper layer of sand has a permeability of approximately $6.68 \mathrm{~m} /$ day. Furthermore, results from the Suradadi Sub-district showed that the permeability value of the clay is $1.46 \times$ $10^{-3} \mathrm{~m} /$ day. However, the groundwater level in this area is shallower than the Balapulang Sub-district but has a low permeability value.

Table 1. Resistivity value of each geoelectrical point in the Tegal District.

\begin{tabular}{|c|c|c|c|}
\hline \multicolumn{2}{|c|}{ Depth (m- from the surface) } & \multirow{2}{*}{$\begin{array}{c}\text { Thickness } \\
\text { (m) }\end{array}$} & \multirow{2}{*}{$\begin{array}{c}\text { Resistivity } \\
\text { (ohm-m) }\end{array}$} \\
\hline From & To & & \\
\hline \multicolumn{4}{|c|}{ GL 1- groundwater level $4.2 \mathrm{~m}$} \\
\hline 0 & 2 & 2 & 28.94 \\
\hline 2 & 6 & 4 & 16.25 \\
\hline 6 & 7.5 & 1.5 & 23.36 \\
\hline 7.5 & 8 & 0.5 & 28.88 \\
\hline 8 & 13 & 5 & 52.82 \\
\hline 13 & 28 & 15 & 14.21 \\
\hline 28 & 65 & 37 & 7.22 \\
\hline 65 & 74 & 9 & 12.83 \\
\hline 74 & 125 & 51 & 3.18 \\
\hline \multicolumn{4}{|c|}{ GL 2 - groundwater level $6.4 \mathrm{~m}$} \\
\hline 0 & 1.2 & 1.2 & 201.68 \\
\hline 1.2 & 8.43 & 7.23 & 32.17 \\
\hline 8.43 & 10.26 & 1.83 & 6.51 \\
\hline 10.26 & 11.86 & 1.6 & 44.97 \\
\hline 11.86 & 40.44 & 28.58 & 309.72 \\
\hline 40.44 & 63.77 & 23.33 & 90.49 \\
\hline 63.77 & 125 & 61.23 & 5.22 \\
\hline \multicolumn{4}{|c|}{ GL 3- groundwater level $4.5 \mathrm{~m}$} \\
\hline 0 & 0.54 & 0.54 & 135.46 \\
\hline 0.54 & 0.55 & 0.01 & 17.97 \\
\hline 0.55 & 2.63 & 2.08 & 6.73 \\
\hline 2.63 & 2.84 & 0.21 & 22.9 \\
\hline 2.84 & 12.42 & 9.58 & 117.47 \\
\hline 12.42 & 25.99 & 13.57 & 11.24 \\
\hline 25.99 & 125 & 99.01 & 6.13 \\
\hline \multicolumn{4}{|c|}{ GL 4 - groundwater level $3.9 \mathrm{~m}$} \\
\hline 0 & 0.61 & 0.61 & 31.94 \\
\hline 0.61 & 2.14 & 1.53 & 8.15 \\
\hline 2.14 & 6.99 & 4.85 & 129.68 \\
\hline 6.99 & 13.02 & 6.03 & 114.3 \\
\hline 13.02 & 21.25 & 8.23 & 17.45 \\
\hline 21.25 & 46.81 & 25.56 & 1.9 \\
\hline 46.81 & 125 & 78.19 & 20.02 \\
\hline \multicolumn{4}{|c|}{ GL 5- groundwater level $1.2 \mathrm{~m}$} \\
\hline 0 & 0.67 & 0.67 & 43.87 \\
\hline 0.67 & 1.87 & 1.2 & 7.48 \\
\hline 1.87 & 3.75 & 1.88 & 4.58 \\
\hline 3.75 & 11.28 & 7.53 & 8.64 \\
\hline 11.28 & 125 & 113.72 & 2.98 \\
\hline \multicolumn{4}{|c|}{ GL 6- groundwater level $2.3 \mathrm{~m}$} \\
\hline 0 & 0.74 & 0.74 & 49.81 \\
\hline 0.74 & 3.27 & 2.53 & 9.99 \\
\hline 3.27 & 10.25 & 6.98 & 2.02 \\
\hline 10.25 & 111.15 & 100.9 & 2.79 \\
\hline 111.15 & 125 & 13.85 & 25.96 \\
\hline \multicolumn{4}{|c|}{ GL 7- groundwater level $1.5 \mathrm{~m}$} \\
\hline 0 & 2.5 & 2.5 & 12.2 \\
\hline 2.5 & 13.61 & 11.11 & 5.61 \\
\hline 13.61 & 32.54 & 18.93 & 1.21 \\
\hline 32.54 & 95.61 & 63.07 & 6.32 \\
\hline 95.61 & 125 & 29.39 & 20.01 \\
\hline \multicolumn{4}{|c|}{ GL 8- groundwater level $3.5 \mathrm{~m}$} \\
\hline 0 & 4.6 & 4.6 & 15.47 \\
\hline 4.6 & 10.21 & 5.61 & 5.12 \\
\hline 10.21 & 58.79 & 48.58 & 2.6 \\
\hline 58.79 & 94.35 & 35.56 & 6.2 \\
\hline 94.35 & 125 & 30.65 & 22.1 \\
\hline
\end{tabular}




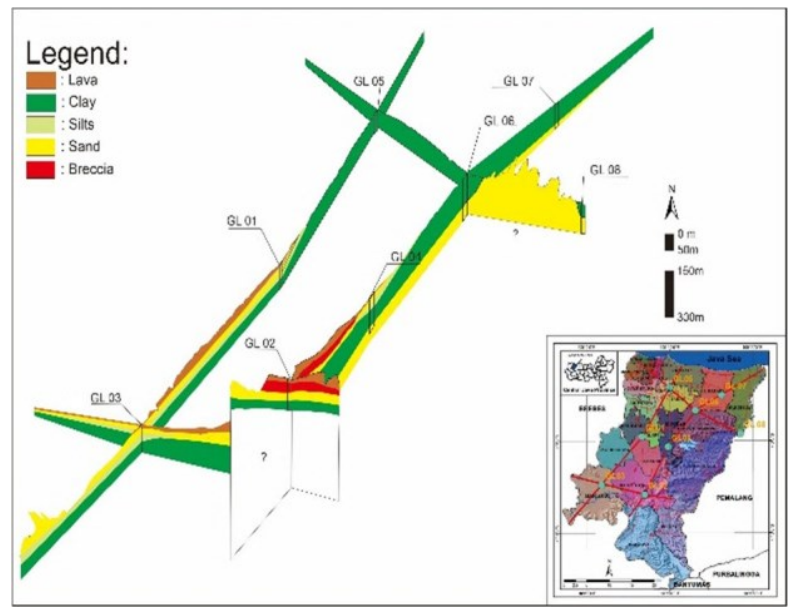

Fig. 3. Fence diagram of stratigraphic in the Tegal District based on the geoelectrical survey.

\subsection{Groundwater resources potential}

The potential of groundwater was estimated using the value of permeability and the thickness of the saturated part of the upper aquifer layer of sand and clay. The calculation of each geoelectrical point using equation 3 , and the result are presented in Table 2. Geoelectrical points of GL-1, GL-3, and GL-4 were categorized as moderate potential, while GL-2 was classified as weak since the other points can be negligible [23]. Therefore, the exploitation of groundwater resources is prioritized in the area of GL-01, GL-3, and GL-4. It belongs to Lebaksiu, Margasari, and Pangkah Sub-districts.

Table 2. Transmissivity value for each geoelectrical point.

\begin{tabular}{|c|c|c|c|c|}
\hline $\begin{array}{c}\text { Geo- } \\
\text { electrical } \\
\text { point }\end{array}$ & $\begin{array}{l}\text { Material } \\
\text { Type and } \\
\text { Thickness }\end{array}$ & $\begin{array}{l}\text { Groundwater } \\
\text { level (m) }\end{array}$ & $\begin{array}{l}\text { Permeability } \\
\text { (m/day) }\end{array}$ & $\begin{array}{c}\text { Transmissivity } \\
\left(\mathrm{m}^{2} / \text { day }\right)\end{array}$ \\
\hline GL-1 & $\begin{array}{l}13 \mathrm{~m} \text { of } \\
\text { sand }\end{array}$ & 4.2 & 6.68 & 58.78 \\
\hline GL-2 & $\begin{array}{l}11.86 \mathrm{~m} \\
\text { of sand }\end{array}$ & 6.4 & 6.68 & 36.47 \\
\hline GL-3 & $\begin{array}{l}12.42 \mathrm{~m} \\
\text { of sand }\end{array}$ & 4.5 & 6.68 & 52.91 \\
\hline GL-4 & $\begin{array}{l}13.02 \mathrm{~m} \\
\text { of sand }\end{array}$ & 3.9 & 6.68 & 60.92 \\
\hline GL-5 & $\begin{array}{l}125 \mathrm{~m} \text { of } \\
\text { clay }\end{array}$ & 1.2 & $1.46 \times 10^{-3}$ & 0.18 \\
\hline GL-6 & $\begin{array}{c}111.15 \mathrm{~m} \\
\text { of clay }\end{array}$ & 2.3 & $1.46 \times 10^{-3}$ & 0.16 \\
\hline GL-7 & $\begin{array}{l}95.61 \mathrm{~m} \\
\text { of clay }\end{array}$ & 1.5 & $1.46 \times 10^{-3}$ & 0.14 \\
\hline GL-8 & $\begin{array}{l}94.35 \mathrm{~m} \\
\text { of clay }\end{array}$ & 3.5 & $1.46 \times 10^{-3}$ & 0.13 \\
\hline
\end{tabular}

\section{Conclusion}

According to the results of the geoelectrical survey, the Tegal district in the lowlands is made up of clay, silt, sand, breccia, and lava deposits. It has two layers of sand as an aquifer, and it is dominated in the south of the plain. The sand layer gradually turns into a smaller size of clay to the north. The upper layer has hydraulic permeability $6.68 \mathrm{~m} \mathrm{~d}^{-1}$. The clay layer in the north has a low permeability of around $1.46 \times 10^{-3} \mathrm{~m} \mathrm{~d}^{-1}$. Therefore, the moderate potential of shallow groundwater resources based on the transmissivity value is located in the middle of the Tegal District, including
Lebaksiu (GL-01), Margasari (GL03), and Pangkah (GL-04) Sub-districts. The area with small groundwater resources potential is Balapulang Sub-district (GL-01). However, the remaining geoelectrical areas do not have significant groundwater resources. The groundwater abstraction is recommended in the middle area of the district since the gravitational pull is directed towards the north area. The exploitation of groundwater in the north area should be minimized due to a lack of resources and to avoid seawater intrusion.

The Authors would like to thanks to Municipal Waterworks of Tegal for the financial support. We also thank the Research Directorate of Universitas Gadjah Mada for facilitating the research.

\section{References}

1. I.A. Shiklomanov. World freshwater resources In Gleick, P.H. (Ed.). Water in Crisis: A Guide to the World's Fresh Water Resources (Oxford University Press, 1993).

2. X. Zhang, Front. Environ. Sci, 3, 59 (2015).

3. K. Benjmel, F. Amraoui, S. Boutaleb, M. Ouchchen, A. Tahiri, A. Touab, Water 12, 471 (2020).

4. P. Rejekiningrum, Jurnal Sumberdaya Lahan 3, 2 (2009).

5. M. Goldman and F.M. Neubaur, Surveys in Geophysics, 15 (1994).

6. Y. Rubin and S. Hubbard, Hydrogeophysics (Springer, Dordrecht, 2005).

7. SA.W. Araffa, Geophysical Journal International, 192, 1 (2013).

8. S.A.S. Araffa, M.I. Mohamadin, H.S. Sabet and M.S. Takey, NRIAG Journal of Astronomy and Geophysics 8, 1 (2019).

9. M. Arsene, B.W.W. Elvis, G. Daniel, N.M. Theophile, K. Kelian, N.J. Daniel, International Journal of Geophysics 2018 (2018).

10. W. Wilopo, D.P.E. Putra, R. Susatio, Journal of Degraded and Mining Lands Management 7, 4 (2020).

11. M. Hasan, Y.J. Shang, W.J. Jin, G. Akhter, Journal of Mountain Science 16, 4 (2019).

12. M. Hasan, Y. Shang, G.Akhter and W. Jin, Water 10, 11 (2018).

13. S. Vann, A. Puttiwongrak, T. Suteerasak, W. Koedsin, Water 12, 506 (2020).

14. L. Nagy, A.T. Akács, T. Huszák, A. Mahler, G. Varga, Comparison of permeability testing methods, in Proceedings of the 18th International Conference on Soil Mechanics and Geotechnical Engineering, Paris (2013).

15. U. Sahin, Environ. Earth Sci. 75, 200 (2016).

16. M.J. Hvorslev, Time Lag and Soil Permeability in Ground-Water Observations, Bull. No. 36, (Waterways Exper. Sta. Corps of Engrs, U.S. Army, Vicksburg, Mississippi, 1951).

17. W.D. Reynolds, Eng. Geol. 185, (2015). 
18. Badan Pusat Statistik Kabupaten Tegal, Kabupaten Tegal Dalam Angka 2019, (Badan Pusat Statistik Kabupaten Tegal, Kabupaten Tegal 2019).

19. R. Kirsch, Groundwater Geophysics: A Tool for Hydrogeology (Springer-Verlag, 2006).

20. M. Goldman and F.M. Neubauer, Surveys in Geophysics, 15 (1994).

21. H. Bouwer and R.C. Rice, 1976. Water Resources Research, 12, 3 (1976).

22. R.I. Imael, Slug Test in Unconfined Aquifers, (Master's Theses, Western Michigan University, 2016).

23. C.W. Fetter, Applied Hydrogeology (PranticeHall, 2001).

24. R.J.M. de Wiest, Groundwater Hydrology, (Academic Press, 1969).

25. L. Turc., Le bilan d'eau des sols. Relations entre les précipitations, l'évaporation et l'écoulement. Annales Agronomiques 5, 491 (1954).

26. P.B.S. Sarma, J.W. Delleur, A.R. Rao, A Program in Urban Hydrology Part II: An Evaluation of Rainfall-Runoff for Small Urbanized Watersheds and the Effect of Urbanization on Runoff, (IWRRC Technical Reports Paper 8, 1969).

27. M. Djuri, H. Samodra, T.C. Amin dan S. Gafoer, Peta Geologi Lembar Purwokerto dan Tegal, Jawa, (Pusat Penelitian dan Pengembangan Geologi, Bandung, Indonesia, 1996).

28. D.K. Todd and L.M. Mays, L.M., Groundwater Hydrology, (John Wiley and Sons Inc., 2005).

29. D. Setiono, H. Pudjiardjo, W. Hidajat, Geological Engineering E-Journal 6, 2 (2014). 